\title{
ESR DATING OF SEDIMENTARY QUARTZ GRAINS: SOME BASIC GUIDELINES TO ENSURE OPTIMAL SAMPLING CONDITIONS
}

\author{
Davinia MORENO ${ }^{1}$, Maïlys RICHARD ${ }^{2}$, Jean-Jacques BAHAIN ${ }^{2}$, Mathieu DUVAL ${ }^{3}$, \\ Christophe FALGUÈRES ${ }^{2}$, Hélène TISSOUX ${ }^{4} \&$ Pierre VOINCHET ${ }^{2}$
}

\begin{abstract}
Electron Spin Resonance (ESR) applied to optically bleached quartz grains extracted from sediment provides an age estimate for the last exposure of sediment to sunlight. This method has been increasingly used in archaeological, geological and geomorphological contexts for the last 30 years. However, its successful application is highly dependent on the geological context and the type and quality of the material sampled. Therefore, appropriate sampling strategy and conditions are crucial to ensure reliable ESR ages. The aim of this paper is to provide basic background information on the best way to collect samples and select the most suitable materials for ESR dating. It is nevertheless highly recommended to contact an ESR geochronologist prior to fieldwork sampling.
\end{abstract}

Keywords : ESR dating, quartz, sampling strategy, sediment

\section{RÉSUMÉ}

DATATION PAR ESR DE GRAINS DE QUARTZ EXTRAITS DE SÉDIMENTS: QUELQUES RECOMMANDATIONS POUR UN PRÉLĖVEMENT OPTIMAL

La datation par la méthode de la résonance de spin électronique (ESR) de quartz blanchis extraits de sédiment permet d'obtenir l'âge du dernier dépôt après exposition des grains de quartz à la lumière du soleil. Cette méthode a été appliquée avec succès en contexte archéologique et géologique durant les trente dernières années. L'application de cette méthode est fortement dépendante du contexte géologique/géomorphologique et de la qualité du matériel prélevé. Par conséquent, une bonne stratégie de prélèvement est cruciale pour obtenir des âges ESR fiables. L'objectif de cet article est de fournir des informations essentielles concernant le mode de prélèvement des échantillons de sédiment les plus adéquats pour une datation par ESR. Néanmoins, il est préférable de contacter un spécialiste de la datation par ESR avant de commencer les prélèvements sur le terrain.

Mots-clés : méthode ESR, quartz, stratégie de prélèvement, sédiment

\section{1 - INTRODUCTION}

The Electron Spin Resonance (ESR) dating of optically bleached quartz grains extracted from sediments has progressively become an important tool for archaeologists, geologists and geomorphologists because this technique is applicable to very diverse archaeological settings and depositional environments (fluvial, marine or aeolian) (e.g. Tissoux, 2015; Duval, 2016). Since the first geochronological application by Yokoyama et al. (1985), the number of publications reporting ESR results likewise the demand for ESR dating studies have considerably increased over the last decades. The aim of the present short paper is to provide a sampling guide for non-dating specialists (usually archaeologists, geologists, geomorphologists or palaeontologists) who need to collect samples on their own for ESR dating purposes. Although the recommendations provided below are relatively straightforward, the involvement of an ESR geochronologist before any fieldwork campaign is nevertheless strongly recommended.

\footnotetext{
${ }^{1}$ Centro Nacional de Investigación sobre la Evolución Humana (CENIEH), Paseo Sierra de Atapuerca, 3. 09002 BURGOS, España. Courriel : davinia.moreno@cenieh.es

${ }^{2}$ Département Hommes et Environnements. Muséum National d'Histoire Naturelle. UMR7194. 1, rue René Panhard. 75013 PARIS, France. Courriel : mailys.richard@mnhn.fr, bahain@mnhn.fr, falguere@mnhn.fr,pvoinch@mnhn.fr

${ }^{3}$ Australian Research Centre of Human Evolution (ARCHE). Environmental Futures Research Institute (EFRI). Griffith University. 170 Kessels Road. NATHAN, QLD4111, Australia. Courriel : m.duval@griffith.edu.au

${ }^{4}$ Bureau de Recherches Géologiques et Minières. GEO/G2R, BP 36009.45060 ORLÉANS Cedex 2, France. Courriel : h.tissoux@brgm.fr
} 


\section{2 - BASIC PRINCIPLES}

The ESR method applied to optically bleached quartz grains extracted from sediments measures the time elapsed since the last exposure of the detrital grains to sunlight (phenomenon called optical bleaching). Once quartz grains are buried and sheltered from sunlight, intensity of the ESR signal associated with paramagnetic centers present in quartz (e.g. Aluminium, Titanium, Germanium centers) naturally grows with time due to its exposure to ionizing radiations emitted by radioisotopes located within the sample and the surrounding sediment, as well as from incoming cosmic rays. The intensity of this ESR signal is then directly proportional to the amount of radiation received by the sample during its geological/ archaeological history $\left(\boldsymbol{D}_{E^{*}}\right.$ : equivalent dose in gray, Gy), the environmental dose rate ( $\boldsymbol{D}$ in $\mathrm{Gy} / \mathrm{ka}$ ) and the time ( $\boldsymbol{t}$ in ka) elapsed since the last exposure to sunlight. An ESR age is therefore calculated by dividing the equivalent dose $\left(\mathrm{D}_{\mathrm{E}}\right)$ by the dose rate (D) (Grün, 1989). This age represents the time elapsed since deposition, not the formation of the quartz mineral. However, if bleaching is incomplete a residual dose added to the equivalent dose will contribute to overestimate the age. An insufficient bleaching is usually linked to the conditions of transport and deposition of the quartz grains (Voinchet et al., 2015). The successful application of the ESR dating method is therefore highly dependent on the geological context as well as the sampling conditions in the field (sampling strategy, type and quality of the material sampled).

\section{3 - BASIC CONSIDERATIONS FOR ESR SAMPLING}

Material selected for ESR dating should fulfil the following criteria: adequate resetting of the ESR signal (optical bleaching), ability to characterize the radioactive environment surrounding the sample (dose rate) and lack of evidence for post-depositional mixing (bioturbation) or reworking (colluvial processes).

To assess whether the sediment was sufficiently exposed to sunlight before its burial, the depositional environment and mode of sediment transport must be carefully characterized because bleaching and sediment transport are directly linked. According to Voinchet et al. (2015), sands carried out by water are usually better bleached at the time of their deposition than aeolian sands. Moreover, within the water transportation mode, the clearest transport environments should be preferred. Therefore, sands transported by clear water reveal being the most appropriate for ESR analyses. It means that it is better sampling pure sands than silty sands. However, even if bleaching is not complete at the deposition time for fluvial, marine or aeolian sands, the low values of the residual dose observed does not prevent dating these sediments by ESR (see further details in Voinchet et al. 2015, table 1). Indeed, the size of the quartz grains has a direct impact on several correction factors that are used for evaluating the dose rate such as $\alpha$ and $\beta$ dose attenuations (Aitken, 1985; Bell, 1979; Duval et al., 2015). Grain size and bleaching levels may also be closely correlated. Whatever the transportation mode (fluvial, marine or aeolian), very fine grains $(62-120 \mu \mathrm{m})$ and coarser grains $(0.5-1 \mathrm{~mm})$ are often less exposed to sunlight during the transport and lead to poor conditions of optical bleaching. Consequently, the intermediate particle size $(100-200 \mu \mathrm{m})$ fraction is usually considered as being the most appropriate for ESR analyses in laboratory because it seems to be better bleached at the time of deposition (Voinchet et al., 2015). Finest and coarser grain size fractions can also be used for dating by ESR but taking into account that the residual dose is higher than for the intermediate particle size. Loess is a special case in which an overestimation of ages is systematically observed due to insufficient bleaching (turbulent transport clouds preventing sunlight contact). In the field, sediment should be examined for evidence of disturbance such as bioturbation (from roots or animals), pedogenic processes (clay illuviation or segregation) or post-depositional reworking because it can mix grains of different ages in a sedimentary profile or alter dose rate conditions over time, respectively (Bateman et al., 2003; Rink et al., 2013). Depending on the paramagnetic centers used (Al or Ti), ESR dating method can be applied on sediment deposited between $50 \mathrm{ka}$ and several million years (Ikeya, 1993).

\section{4 - SAMPLING GUIDELINES FOR COLLECTING SEDIMENT SAMPLES}

For the ESR age calculation, ESR dating laboratories usually require two separated sediment samples for each sample: a light-shielded sample used for the equivalent dose $\left(\mathrm{D}_{\mathrm{E}}\right)$ determination and a bulk sample of the surrounding sediments for determining the dose rate (D) and evaluate the actual water content. Fig. 1 shows all material needed for sampling.

Sampling conditions are very similar to those for Optically Stimulated Luminescence (OSL) dating, although it should be mentioned that ESR signal are much less light sensitive than the OSL signals (see fig. 1 in Duval et al.., 2017). Samples for $\mathrm{D}_{\mathrm{E}}$ analysis must be collected in a light-proof container such as pre-sharpened (only sharpened on one end) PVC or metal tubes of about $20 \mathrm{~cm}$ in length by $6.5 \mathrm{~cm}$ in diameter. Smaller tubes can of course be used, but one should keep in mind that the amount of pure quartz required for ESR measurements is of $\sim 3-4 \mathrm{~g}$, i.e. somewhat higher than that for OSL dating (see an example in section 6.5 from Duval et al.., 2017). A metallic cap may be used so that the tube can be easily hammered horizontally into the outcrop. This should be done after a previous cleaning of the section of $\sim 5 \mathrm{~cm}$ in order to make a freshly exposed surface (fig. 2). Following the sample collection, both ends of the tube should be sealed with tape to prevent light exposure and loss of sediment. Clearly 


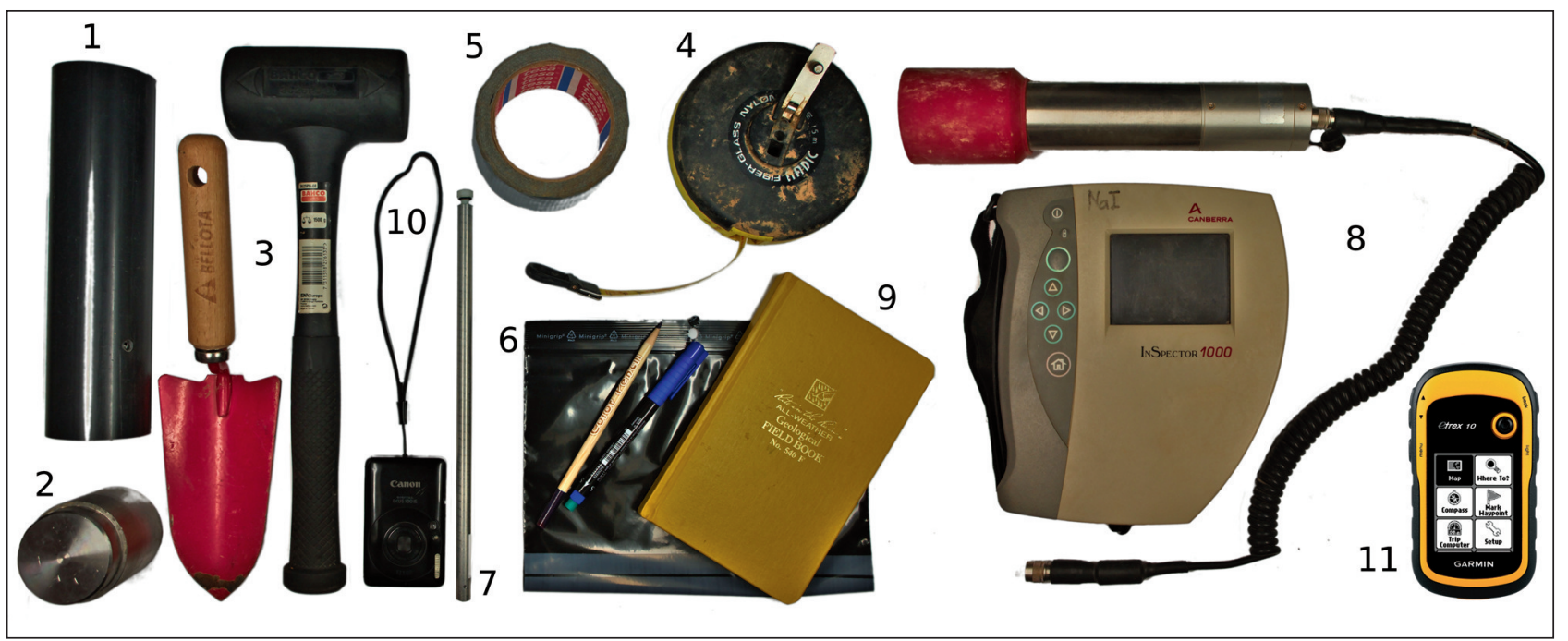

Fig. 1 : Example of field material necessary for ESR sampling

(1) PVC or metal tubes, (2) metal cap, (3) hammer and hand trowel, (4) measuring tape, (5) Duct tape (6) opaque ziplock bag, dark-colored permanent pen and pencil (7) dosimeter, (8) field-portable gamma spectrometer, (9) field notebook, (10) photo camera et (11) portable GPS (Photo: Mario Modesto Mata).

Fig. 1 : Exemple du matériel nécessaire au prélèvement de sédiment et à la mesure de la dose in situ pour la datation par ESR, incluant: (1) tubes métalliques ou en PVC, (2) bouchon métallique, (3) marteau et truelle, (4) mètre, (5) scotch, (6) sacs opaques, marqueur permanent et crayon, (7) dosimètre, (8) spectromètre gamma portable, (9) carnet de terrain, (10) appareil photo et (11) GPS portable.

label the sample (using preferably a permanent darkcolored pen) by indicating for example the acronym obtained from the name of the site, year of collection and sample number (e.g., Atapuerca, 2017, sample 24: ATA1724). Finally, the tube (sealed and labelled) should be introduced into an opaque ziplock bag labelled with the same code. If the sediment is too hard or compact to insert a tube, then other sampling techniques can be used. For example, a block of sediment can be carved and securely wrapped with aluminium foil and tape. Then it must be placed in opaque plastic bags or bigger containers for transport to the laboratory where it will be prepared under controlled light conditions. In the case of coarse-grained alluvial deposits where sand lenses are too thin to sample with a tube or a block, the sandy matrix within the gravel (or loose sediment) can also be collected in a light-proof container under an opaque plastic cover.

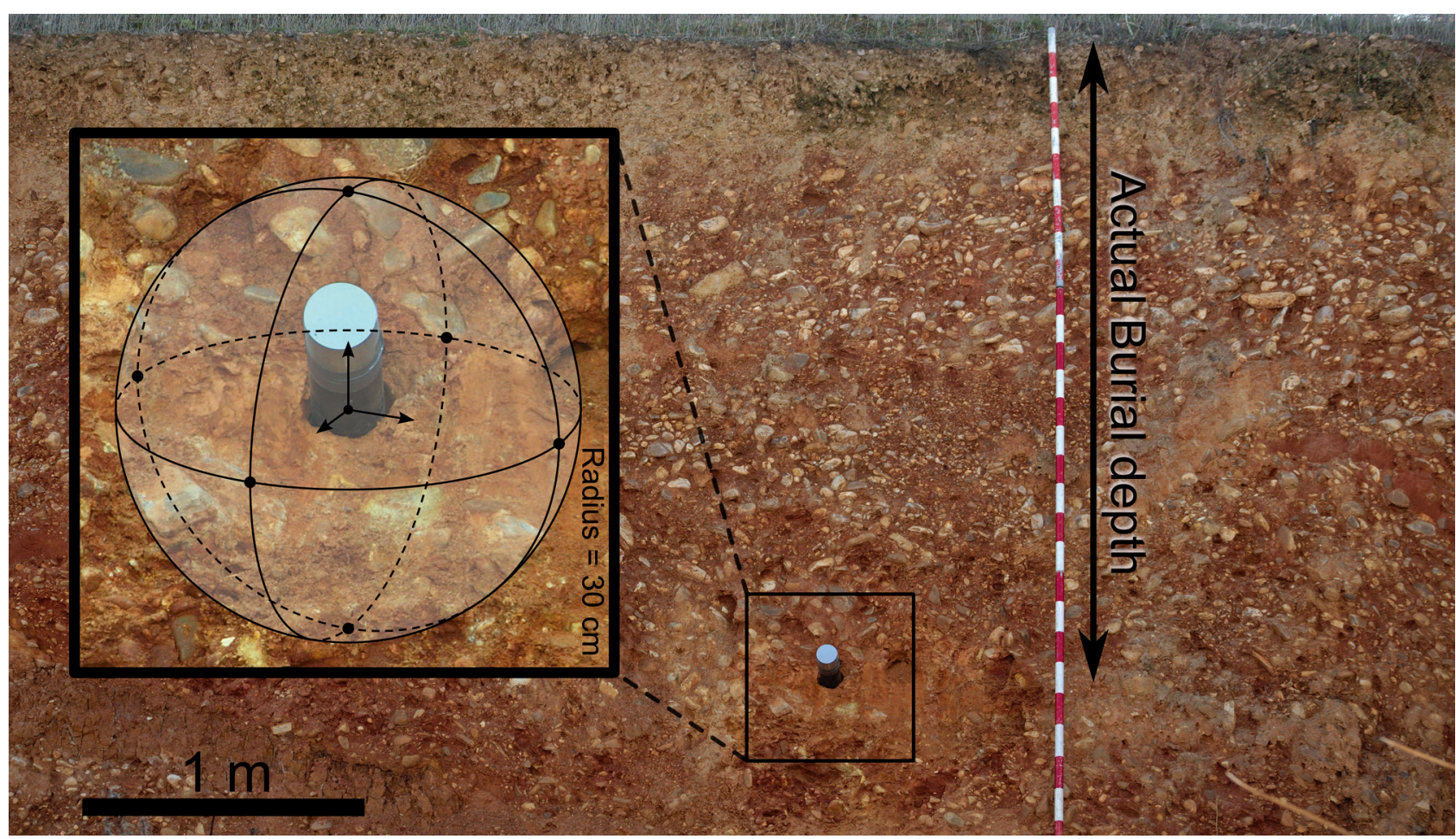

Fig. 2 : Picture showing the collection of a sediment sample by hammering a PVC tube into an outcrop exposure and the measurement of the burial depth.

The sphere represents the $\gamma$ radiation influence in a $30 \mathrm{~cm}$ diameter around the dating sample (Photo: Mario Modesto Mata).

Fig. 2 : Prélèvement d'un échantillon de sédiment en introduisant le tube dans le profil stratigraphique et mesure de la profondeur à laquelle l'échantillon a été pris. La sphère représente l'influence $\gamma$ autour de l'échantillon. 
The external dose rate (D) evaluation is based on the determination of $\alpha, \beta, \gamma$ and cosmic components. $\alpha$ and $\beta$ dose rates should preferentially be obtained from the raw sediment collected at the sampling spot, while the gamma dose rate would ideally require an in situ measurement, although it may not always be possible. In this context, bulk sediment samples for D analyses and moisture content should be collected from the ESR sampling site (tube hole) or from a $30 \mathrm{~cm}$ radius sphere around the sample (fig. 2). Radioelement concentrations or activities may be derived from various techniques, such as total $\beta$ counters (requiring a few grams of raw sediment), ICP-MS ( $\sim 150 \mathrm{~g})$ or High Resolution Gamma Spectrometry (approximately $100-150 \mathrm{~g}$ is sufficient). Samples should be bagged and clearly labelled using the same acronym to that ESR sample. In addition, the evaluation of the in situ gamma dose rate can be done using either a field portable gamma spectrometer (fig. 3) (Mercier \& Falguères, 2007) or TL-OSL (Thermo and Optically Stimulated Luminescence) dosimeters. Dosimeters have to be inserted at least $30 \mathrm{~cm}$ deep into the section for between six months and a year. Consequently, the site should be accessible and secured to avoid any

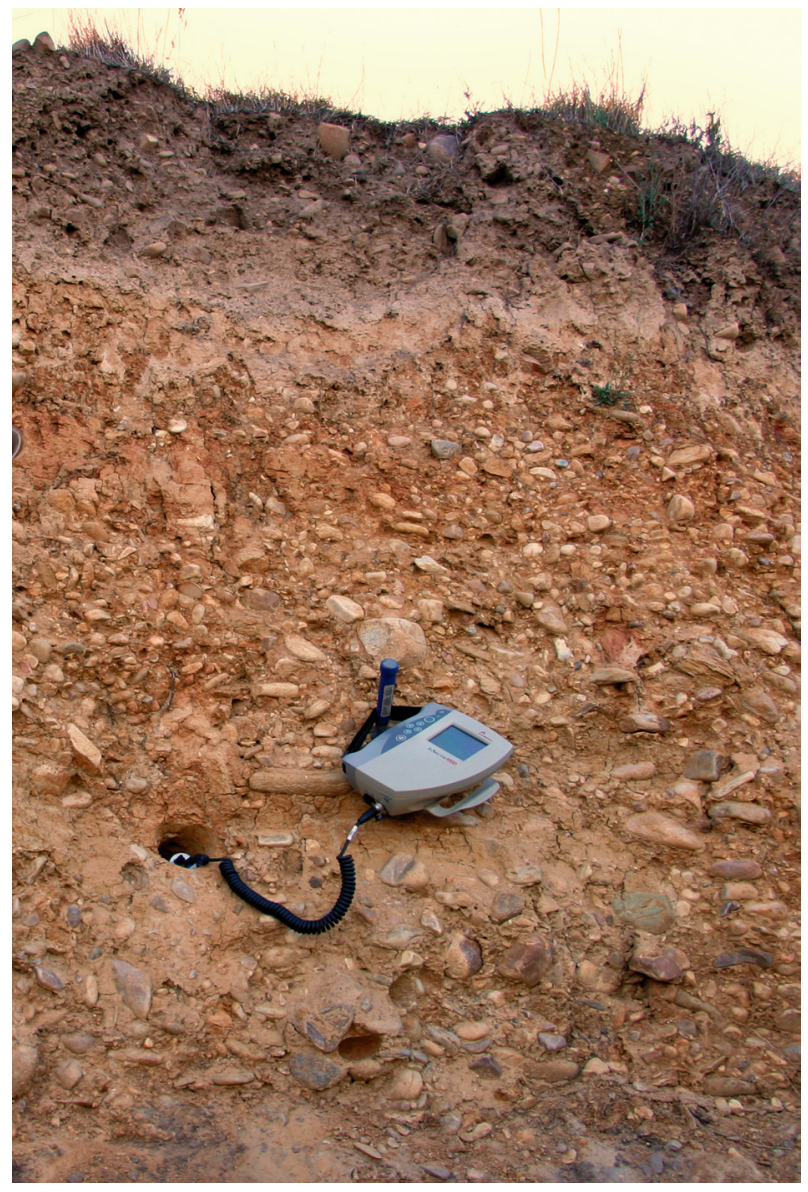

Fig. 3 : In situ $\gamma$ spectrometry measurements accurately capture the $\gamma$ dose rate.

This is especially important in heterogeneous sedimentological contexts (see picture) where it is difficult to reconstruct the dose rate through chemical analysis performed in the laboratory (Photo: Davinia Moreno).

Fig. 3 : Les mesures $\gamma$ in situ à l'aide d'un spectromètre gamma portable permettent de mesurer avec précision la dose $\gamma$. Ceci est particulièrement important dans des contextes sédimentologiques hétérogènes où il est difficile de reconstruire la dose annuelle à partir des analyses chimiques dans le laboratoire. perturbation or loss during that period. Dosimeters can be capsules of only $10 \mathrm{~mm}$ diameter, which minimise the disruption/damage to the site or outcrop. Another advantage is that the gamma dose rate registered over such a long period is also by definition indirectly taking into consideration any fluctuations of the water content of the sediment with time. In contrast, the field portable gamma spectrometer is more frequently used because the measurement can be completed almost immediately (around half an hour usually). It is therefore possible to carry out several measurements within a day. However, depending of the size of the probe (usually with a diameter of 3.8 or $5 \mathrm{~cm}$ ), a hole of at least $5 \mathrm{~cm}$ diameter by about $30 \mathrm{~cm}$ deep is required to ensure an in situ gamma dose rate measurement. In both cases, measurements must be carried out at the exact ESR sampling spot. Furthermore, information on the latitude, longitude and elevation of the site and burial depth of the sample (fig. 2) should be reported in order to calculate the cosmic contribution to the total dose rate (D). If the sample burial depth has changed over time (erosion, deposition history, excavation), burial depth evolution must be reconstructed. The use of a portable handheld GPS device is highly recommended in order to obtain accurate coordinates.

Stratigraphic logs, pictures of the sample locations, profiles sketches, maps and any other information to illustrate stratigraphic relationships between samples or identify potential problems with partial bleaching should be included.

\section{5 - SAMPLING FORM FOR ESR DATING OF QUARTZ}

All the recommendations presented here have been summarised in a sampling form (fig. 4) intended for archaeologists, geologists and geomorphologists who want to collect quartz samples for ESR dating. This form has been divided into four main sections: Site, Sample, in situ dosimetry and cosmic dose rate evaluation. Finally, there is an empty column where stratigraphic logs indicating the exact location of samples and any other information about the site should be reported. It is important to note that the present work and associated sampling form only provide some guidelines about the sample collection method and the minimum information required for ESR dating. Depending on the context and the complexity of the site additional information may sometimes be required.

\section{6 - CONCLUSIONS}

Fieldwork is a key step in the procedure to obtain reliable ESR ages. Indeed, many issues observed in the laboratory are directly associated with the sampling : loss of ESR signal due to exposition of sediments to light or lamps, missing the additional bulk sample for water content or dose rate analyses, lack of information about depositional context, stratigraphy or burial depth, sedi- 


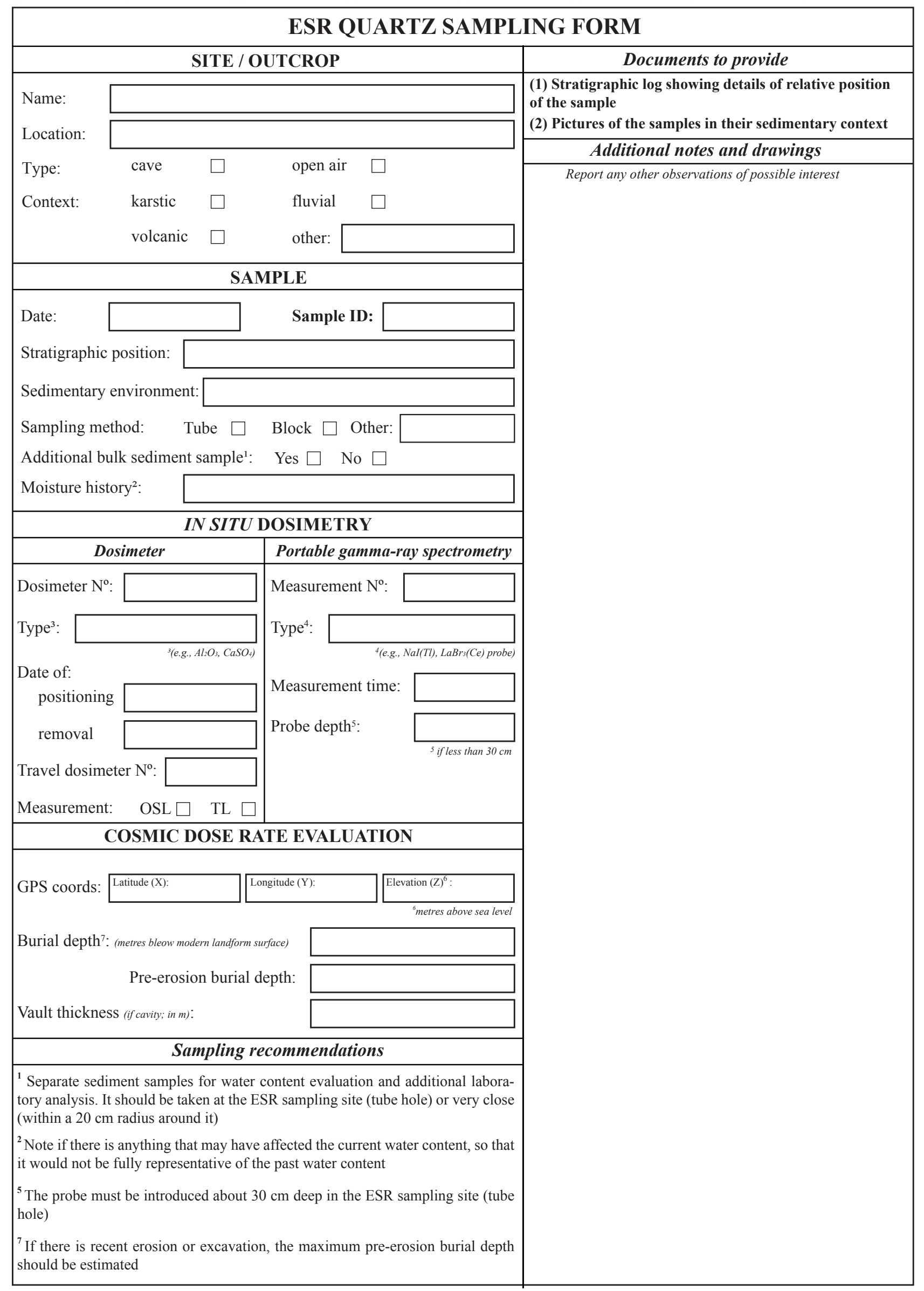

Fig. 4 : ESR quartz sampling form.

Fig. 4 : Fiche d'échantillonnage pour la datation par ESR de grains de quartz. 
ments taken from deposits that have been affected by post-depositional processes or unadapted depositional environment, etc. Recommendations explained in this paper along with the sampling form should help archaeologists and geologists to avoid, or at least minimise, all these problems. However, an ESR geochronologist or ESR dating laboratory should always be contacted prior to sample collection in the field.

\section{ACKNOWLEDGEMENTS}

M. Duval is currently the recipient of an Australian Research Council Future Fellowship (FT150100215). We thank Sanda Balescu for her careful reading of the manuscript that improved the clarity.

\section{REFERENCES}

AITKEN M.J., 1985 - Thermoluminiscence dating. Academic Press, London. 359 p.

BATEMAN M.D., FREDERICK CD., JAISWAL MK \& SINGHVI AK., 2003 - Investigations into the potential effects of pedoturbation on luminescence dating. Quaternary Science Reviews, 22, 1169 1176

BELL W.T., 1979 - Attenuation factors for the absorbed radiation dose in quartz inclusions for thermoluminescence dating. Ancient TL, 8.
DUVAL M., 2016 - Electron spin resonance (ESR) in archaeological contexts. Encyclopedia of Geoarchaeology. A.S. Gilbert, Springer, 224-233.

DUVAL M., CAMPAÑA I., GUILARTE V., MIGUENS L., IGLESIAS J. \& GONZÁLEZ SIERRA S., 2015 - Assessing the uncertainty on particle size and shape: implications for ESR and OSL dating of quartz and feldspar grains. Radiation Measurements, 81, 116-122.

DUVAL M., ARNOLD L.J., GUILARTE V., DEMURO M., SANTONJA M. \& PÉREZ-GONZÁLEZ A., 2017 - Electron Spin Resonance dating of optically bleached quartz grains from the Middle Palaeolithic site of Cuesta de la Bajada (Spain) using the multiple centres approach. Quaternary Geochronology, 37, 82-97.

GRÜN R., 1989 - Electron Spin Resonance (ESR) dating. Quaternary International, 1, 65-109.

MERCIER N. \& FALGUÈRES C., 2007 - Field gamma dose rate measurement with a $\mathrm{NaI}(\mathrm{Tl})$ detector: re-evaluation of the "threshold" technique. Ancient TL, 25 (1), 1-4.

RINK W.J., DUNBAR J.S., TSCHINKEL W.R., KWAPICH C., REPP A., STANTON W., \& THULMAN D.K., 2013 - Subterranean transport and deposition of quartz by ants in sandy sites relevant to age overestimation in Optical Luminescence dating. Journal of Archaeological Science, 40 (4), 2217-2226.

VOINCHET P., TOYODA S., FALGUERES C., HERNANDEZ M., TISSOUX H., MORENO D. \& BAHAIN J.J., 2015 - Evaluation of ESR residual dose in quartz modern samples, an investigation on environmental dependence. Quaternary Geochronology, 30, 506-512.

TISSOUX, H., 2015 - Sediment, ESR. Encyclopedia of Scientific Dating Methods. J.W. Rink and J. Thompson. Dordrecht, Springer Netherlands, 743-747.

YOKOYAMA Y., FALGUÈRES C. \& QUAEGEBEUR J.P., 1985 - ESR dating of quartz from Quaternary sediments: first attempt. Nuclear Tracks and Radiation Measurements, 10 (4-6), 921-928. 